Mini Review

\title{
A Critical Review on Sino-South Asian Economic Relations in the Context of Belt and Road Initiative (BRI)
}

\author{
Md. Sayedur Rahman ${ }^{1,2 *}$, Akkas Ahamed ${ }^{3}$ \\ ${ }^{1}$ Department of Political Science, Faculty of Social Sciences, Begum Rokeya University, Rangpur-5400, Bangladesh \\ ${ }^{2}$ Master's Programme in Socioeconomic and Political Development of Modern Asia, Faculty of World Economy and International Affairs, \\ National Research University Higher School of Economics, Moscow, Russian Federation, Email: sayedur34@gmail.com \\ ${ }^{3}$ Department of Political Science, University of Chittagong, Chittagong-4331, Bangladesh, Email: akkas_cu@yahoo.com
}

\section{Article Information}

Received: 20 June 2020

Revised version received: 09 July 2020

Accepted: 12 July 2020

Published: 27 July 2020

\section{Cite this article as:}

M.S. Rahman and A. Ahamed (2020) Int. J. Soc. Sc. Manage. 7(3): 94-104.

DOI: $10.3126 /$ ijssm.v7i3.29964

\section{*Corresponding author}

Md. Sayedur Rahman,

Department of Political Science, Faculty of Social Sciences, Begum Rokeya University, Rangpur-5400, Bangladesh

Email: sayedur34@gmail.com

Peer reviewed under authority of IJSSM

(C) 2020 IJSSM, Permits unrestricted use under the CC-By-NC license.

\section{OPEN A ACCESS}

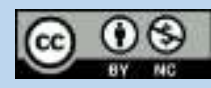

This is an open access article $\&$ it is licensed under a Creative Commons Attribution Non-Commercial 4.0 International (https://creativecommons.org/licenses/by-nc/4.0/)

\begin{abstract}
South Asia which is the southern region of Asia bordering with China, Central Asia, and West Asia. South Asia comprises Afghanistan, Bangladesh, Bhutan, India, Maldives, Nepal, Pakistan, and Sri Lanka. Geographically, it is dominated by the Indian Plate and defined extensively by the Indian Ocean on the southern region, and the Himalayas' hills and the Karakoram mountains on the northern part. On the other hand, China is a country in East Asia, which is the world's most populous country, with a huge population size of around 1.4 billion, according to the survey of 2019. Both the regions have been maintaining friendly relations for several decades since the birth of South Asian countries and the Chinese revolution in 1949. Currently, China is a rapidly growing economy which has been turned into the biggest economy of the World, taking into account of its GDP based on purchasing power parity (PPP). Thus, many scholars think that the Chinese economic involvement in the South Asian countries can create huge opportunities for both regions. The current trade imbalance between China and South Asia needs to be readdressed to ensure a win-win situation for both regions in the context of economic relations. At the end of this article, some policy recommendations have been provided to reduce the political tension between India and China and India and Pakistan. Finally we have recommended some policies to increase economic activities in the region and to speed up the sustainable development.
\end{abstract}

Keywords: China; South Asia; Relations; BRI; Trade and Economic; Geo-politics

\section{Introduction}

It is usual that being the bordering and neighboring regions these two regions should have more intimate relations in light of the economic transactions and trade relations. Enhancement in the bilateral economic relations may help boost up the economic growth and development for the both regions. Both the regions are very important in terms of geopolitical, and geo-economic and geo-strategic aspects. In terms of land surface area, South Asia covers about $11.71 \%$ of the Asian total land area. The size of the population of South Asia making the region as the most densely populated 
geographical sub-continent in the world (South Asia Regional Overview, 2018). The South Asian nations have established a regional organization in 1985 incorporating all eight countries of South Asia. The South Asian Association for Regional Cooperation (SAARC)' which is a political and economic cooperation organization in the region.

Besides, in terms of Chinese political system, the country is governed by one-party system, the Communist Party of China, where the state has supreme jurisdictional powers over five autonomous regions, 22 provinces, and four direct-administered municipalities (Beijing, Tianjin, Shanghai, and Chongqing). Also, the special administrative regions of Hong Kong and Macau are administered and controlled by China (Lams, 2018). The South Asian region had traditionally enjoyed a respected appearance amongst the Chinese people. For the last 2000 years, this opinion has since been confirmed by a series of archaeological findings as too by printed records that hint Sino-South Asian contacts and exchanges of views to 221 BC. Yet, these communications were intermittent and limited to culture and trade; they established a big impact on their development over the centuries with the philosophy of Buddhism providing the toughest links and exchanges between the two societies, and regions. This constructive image was to accept its stern blow with the alliance of the British Empire in the South Asia, Indian subcontinent. Colonialist plans of the British confronted with the Chinese 'Middle Kingdom' superiority which resulted in the Opium Wars (1840); and later an armed expedition into the region of Tibet (1905). Through these old inheritances of undecided border claims, intersecting communities, uprisings, wars and subsequent reciprocated doubts that were to mostly determine Beijing's geo-political and economic interests vis-a-vis the region of South Asia. This link was more strengthened by the Cold War bi-polarism which was partially accountable for the Sino-Indian war of 1962. Based on this war, the rise of a Sino-Pak relationship has subsequently dominated the security related debates between South Asian countries and China (Singh, 2000).

In addition, China has 2500 miles of long borders with the region. Its militarily and economically major position in the Asian region and Beijing's acknowledgment by U.S.A has conferred on her a superior role in the South Asian region. Small states of the region remain too understated from the security pattern due to China's vast military, industrial and nuclear weapons and power. According to Indian scholars, credibly sufficient, China postures both conventional and non-conventional pressures to the whole region, although opposed by Pakistan. By dint of geographic location, China always enjoys a special benefit. Because of its landscape, India is not in a suitable position to carry out an effectively straight attack on the Chinese territories (Jain, 1991). Also, China has a strong political power above South Asian countries, including India, in light of its marine and nuclear- powered abilities. China's traditional knowledge says that border disputes have been the core cause of inter-state threat views. Belt and Road Initiative (BRI) is not only to achieve China's worldwide ambitions, but also its internal needs for instance, to overcome China's energy dependences, taking necessary steps for the development of western China, to reduce the extra-capacity in manufacturing, decaying exports, to promote the geo-globalization, to internationalize the RMB, and to reform the global financial governance (Tekdal, 2018: 378).

India's policy analyst Mohan Guruswamy, debated that "China has amassed foreign exchange reserves of US\$3.5 trillion and the capital is arranged to contribute for the NDB, AIIB and SRF, which would amount to only about 7 percent of its entire foreign exchange reserves which has been put in western banks. Furthermore, the China-backed organizations will be providing infrastructure offering rather than financial grants, the profit on money from these investments could be meaningfully advanced than the revenues China is receiving from its foreign exchange reserves presently invested in low-yielding US government bonds" (Guruswamy, 2017). Some analysts even think that China's plan is not similar to the normal imperialist, but it is packed and endorsed as BRI. Largely, in spite of BRI getting diverse signals from the global community and experts, it has increased acceptability to a large extent through holding of the BRI forum on 14-15 May 2017 (the second BRI forum was held in April 2019) at Beijing. This meeting was attended by the key powers, 29 heads of state and 130 delegations and 70 worldwide organizations. More than 68 countries have signed up the initiative, in spite of countries like Japan, the US, France, UK, and Germany uttering their worries over the BRI, and they sent representatives for the BRI Forum (Rana, 2017: 12; Surendra, 2019). In this regard, the study tries to identify the key issues for China to implement the initiates of BRI and its impression on its stable rise and the regions of South Asia, Central Asia, West Asia and Southeast Asia. Moreover, India's responses and policy to BRI have been critically analyzed in this study as well. Finally, this paper also has discussed the mutual opportunities and development tasks for both South Asia and China considering the geo-political importance of the both regions (Surendra, 2019). The various issues of the economic relations between the regions have been discussed in the article.

\section{The Belt and Road Initiative of the Government of China}

The BRI talks about conveying China's local, regional and sub-national involvements to an international level. There is an inconsistency among the different regions of China. From this standpoint, while being an international scale initiative at the same time, it helps sub-national level 
development aims of China similar to GMS and CAFTA. Mr. Le Yucheng, Executive vice Foreign Minister, said while addressing the Reception Dinner of the First Conference of the Advisory Council of the Belt and Road Forum on International Cooperation (BRF) on 15th of October 2018, 'China, despite being a rapid growing economy, is challenged with socio-economic development imbalances among the different regions. The less developed western area, which has $72 \%$ of China's mainland and $27 \%$ of its entire population, accounts for an unassertive $20 \%$ of the GDP and $7 \%$ of overseas trades and outbound investments of China' (Yucheng, 2018).

China's dialogue is about collaborating with the developing countries along the Eurasian zone in constructing national level infrastructures and development related multiprojects. China has wide experiences of converting into an industrially developed state, thanks to industrial policies and their proper implementation, developing regional connectivity, enhancing cooperation and promoting geopolitical and economic openness. President Xi indicated that 'We have heightened coordination and harmonization with the policy initiatives of applicable countries, for instance, One Economic Circle initiative of Viet Nam, the Master Plan on ASEAN Connectivity of the region, the Eurasian Economic Union of Russia along the Russian and Eurasian region, the Development of Road initiative for Mongolia, the Bright Road initiative for Kazakhstan, the Middle Corridor initiative of Turkey, the Two Corridors, the Northern Powerhouse initiative of the UK, and the Amber Road initiative of Poland' (Yucheng, 2018).

\section{China-India Trade, Investment and Economic Relations}

Both China and India are neighboring countries with long borders. Most of the South Asian and Chinese scholars think that both countries should maintain friendly relations and should reduce their existing trade imbalance through increasing trade volumes. However, there is a huge gap in terms of trade and investment between the two nations. For example, trade deficit between China and India is around 50 billion dollars. Indian markets are full of Chinese products. Of course, it is because of the cheap price of the products. However, some foreign direct investments from China come to some business sectors in India, such as metallurgical industries, renewable energy (solar panels), electrical equipment, automotive and chemicals. Data compiled by Bloomberg Quint from China Global Investment Tracker showed Chinese FDI into India at \$4.14 billion in 2019. China's commerce ministry, however, pegs the figure at $\$ 8$ billion for 2018-19 (Kapoor, 2020). They have roughly 75 manufacturing facilities for smartphones, consumer appliances, construction equipment, power gear, automobiles, optical fiber, and chemicals. Oppo, Vivo, Fosun International, Haier, SAIC and Media are some of the largest Chinese brands and manufacturers in India. Adani Global Ltd., Dr. Reddy's Laboratories Ltd., Jindal Steel \& Power Ltd., BEML Ltd, Bharat Heavy Electricals Lt. Chinese smartphones brands, led by Xiaomi, Vivo and Oppo, are market leaders in India with an estimated $72 \%$ share put together, leaving Samsung and Apple behind, according to a report by Gateway House.

India's pharmaceutical industry is the third largest in the world by volume and ranks 14 by value. The country exported medicines worth over $\$ 14$ billion to the U.S. in 2018-19, according to a response to a query in the Rajya Sabha in March. But, according to the same reply, India imports two-thirds of its active pharmaceutical's ingredients, or key ingredients of drugs, from China (Kapoor, 2020). Travel between India and China has been growing. Or at least it was before the Covid-19 pandemic. Mainland China was the eighth-largest market for India in 2018 with nearly $3 \%$ share in total arrivals. From just 1,371 arrivals in 1981, the number rose to 2.8 lakh in 2018, growing at an annualized rate of $32.4 \%$, according to data available with the Tourism Ministry of India. Chinese funds and companies often route their investments in India through offices located in Singapore, Hong Kong, and Mauritius, a Gateway House report said. For example, Alibaba Group's investment came in India via Alibaba Singapore Holdings Pvt. These don't get recorded in India's government data as Chinese investments, the report said. "In several cases, the investment in India hasn't been calculated. According to App Annie's, the State of Mobile in 2019 report, India saw a $165 \%$ increase in app downloads between 2016 and 2018, (Kapoor, 2020). India imports around 6000 commodities from 140 countries.

The Table 1 shows the India's largest imports partners. The table discusses that China is the largest imports partner of India, not any other country. The USA and UAE have acquired the second and third position respectively in the context of their exports to India. Here it shows that in the fiscal years of 2019-20, China's exports to India are US\$ 57.9 billion. Where USA's exports to India are 30.5 billion; and UAE's export to India are US\$ 25.8 billion. Saudi Arabia and Iraq have attained fourth and fifth position in the rank. Because these two countries export oil to India.

The data shown in Table 1 shows that India's largest imports partner is China. In the fiscal year of 2019 and 2020, India imported different goods from China, whose market value is US\$ 59.7 billion. The US has become the second largest imports partner of India after China. Compared to the Chinese exports in India, the imports from India to China is very low. And there is remaining a huge trade imbalance between the two countries. It is believed that the BRI will help reduce trade imbalance between the two countries. 
Table 1: The below table shows India's 10 largest sources of imports in 2019-2020.

\begin{tabular}{|l|l|l|l|}
\hline Rank & Country & $\begin{array}{l}\text { Value (US\$ } \\
\text { billion) }\end{array}$ & $\begin{array}{l}\text { Share of } \\
\text { overall imports }\end{array}$ \\
\hline 1 & China & 57.9 & $14.37 \%$ \\
\hline 2 & United States & 30.5 & $7.57 \%$ \\
\hline 3 & $\begin{array}{l}\text { United Arab } \\
\text { Emirates }\end{array}$ & 25.8 & $6.39 \%$ \\
\hline 4 & Saudi Arabia & 23.0 & $5.70 \%$ \\
\hline 5 & Iraq & 19.8 & $4.91 \%$ \\
\hline 6 & Switzerland & 14.8 & $3.67 \%$ \\
\hline 7 & Hong Kong & 14.6 & $3.63 \%$ \\
\hline 8 & South Korea & 13.2 & $3.28 \%$ \\
\hline 9 & Indonesia & 12.8 & $3.17 \%$ \\
\hline 10 & Singapore & 12.2 & $3.02 \%$ \\
\hline
\end{tabular}

[Source:

https://en.wikipedia.org/wiki/List_of_the_largest_trading_partner s_of_India, accessed on 27, June 2020]

India exports approximately 7500 commodities to about 192 countries. The Table 2 has discussed about the India's exports destination. It shows that its largest exports partner is USA, not China. UAE is the second largest exports partner; and China is the third largest exports partner. Hong Kong and Singapore acquired the fourth and fifth position respectively in terms of their imports from India.

According to the Table 2, we see that the Indian exports volume to China is US $\$ 14.4$ billion, while at the same fiscal year of 2019-20, the Chinese exports to India is US\$ 59.7 billion. The data clearly shows that the trade imbalance between the two countries. More economic involvement with the South Asian region is crucial to minimize the trade gap. Moreover, many hope that if the BRI and BCIM are implemented properly, these initiatives will help decrease the remaining trade deficit between the two regions.
Table 2: The below table shows India's 10 largest destinations for exports in 2019-2020.

\begin{tabular}{|l|l|l|l|}
\hline Rank & Country & $\begin{array}{l}\text { Value (US\$ } \\
\text { billion) }\end{array}$ & $\begin{array}{l}\text { Share of } \\
\text { overall imports }\end{array}$ \\
\hline 1 & United States & 52.4 & $16.94 \%$ \\
\hline 2 & $\begin{array}{l}\text { United Arab } \\
\text { Emirates }\end{array}$ & 24.3 & $9.20 \%$ \\
\hline 3 & China & 14.4 & $5.47 \%$ \\
\hline 4 & Hong Kong & 9.3 & $3.53 \%$ \\
\hline 5 & Singapore & 7.6 & $2.90 \%$ \\
\hline 6 & $\begin{array}{l}\text { United } \\
\text { Kingdom }\end{array}$ & 7.4 & $2.80 \%$ \\
\hline 7 & Netherlands & 7.1 & $2.69 \%$ \\
\hline 8 & Germany & 7.0 & $2.65 \%$ \\
\hline 9 & Bangladesh & 6.7 & $2.54 \%$ \\
\hline 10 & Nepal & 6.0 & $2.28 \%$ \\
\hline
\end{tabular}

[Source: Government of India, Ministry of Commerce \& Industry, Department of Commerce",

https://en.wikipedia.org/wiki/List_of_the_largest_trading_partner s_of_India, accessed 28 June, 2020]

The Table 3 discusses about the India's largest trading partners in terms of its total exports and imports. The Table 3 shows that in terms of both exports and imports China has become the India's largest trading partner. The USA, UAE and Kingdom of Saudi Arabia (KSA) have attained the second, third and fourth position respectively. Here it should be mentioned that the trade volume between India and UAE, and India and KSA is high because India imports oil from these two petroleum exporting countries. In the table Switzerland is shown in the fifth position in terms trade relations with India. India's total trade with china is US\$ 84.4 billion. The table shows a huge trade imbalance between India and China. But India's trade relations with USA is in favor of India (Table 3).

Table 3: The Largest Trading Partners of India according to the data of 2020:

\begin{tabular}{|l|l|l|l|l|l|}
\hline Rank & Country & Exports & Imports & Total Trade & Trade Balance \\
\hline- & Remaining Countries & 126.78 & 104.92 & 231.70 & 21.86 \\
\hline \multicolumn{2}{|l|}{ India's Total } & 262.29 & 381.01 & 758.30 & -137.63 \\
\hline 1 & China & 16.34 & 68.06 & 84.4 & -51.72 \\
\hline 2 & United States & 48.6 & 25.7 & 74.3 & 22.9 \\
\hline 3 & United Arab Emirates & 30.29 & 19.45 & 49.74 & 10.84 \\
\hline 4 & Saudi Arabia & 6.39 & 20.32 & 26.72 & -13.93 \\
\hline 5 & Switzerland & 0.98 & 19.30 & 20.28 & -18.32 \\
\hline
\end{tabular}

[Source: https://en.wikipedia.org/wiki/List_of_the_largest_trading_partners_of_India, accessed on 27, June 2020] 
The Table 3 shows that in terms of imports and exports, India's largest trading partner is China. The US and other countries come after China while doing business with India. Till the mid of 2020, the Chinese exports to India are US \$ 68.06, and at the same time the Indian exports to China are US\$ 16.34 dollar. The trade deficit is about US\$ 52 billion. Despite the fact, there is always remaining a geo-political, geo-strategic and military tension between China and India. Both the countries may come forward to mitigate the remaining issues; and can take several measures to promote the business environment in the region.

\section{China-Bangladesh Trade, Investment and Economic Relations}

Accordingly, the two tested friends are in action in the areas of mega projects. Bangladesh has become one of the first countries in South Asian region to support the construction of the Belt \& Road, and also an active follower and participant in the construction of the BCIM-EC (Bangladesh, China, India and Myanmar economic corridor) (Surendra, 2019). The rising attainment in relations between the two friendly countries has been replicated in a series of landmark development cooperation initiatives. For example, construction of $\$ 3.7$ billion Padma Bridge in which the Chinese government has provided $\$ 3.0$ billion for the project implementation as portion of a broader plan to spend $\$ 30$ billion on Bangladeshi infrastructure projects. These projects are also being implemented on the funds of Chinese government: The Construction of Dhaka-Chittagong Highway's 4-lane extension project, believed to be the largest road infrastructure project in Bangladesh; Purchasing of more than 25 percent shares of Dhaka Stock Exchange by Shenzhen-Shanghai Stock Exchange Group; The Padma Bridge Rail- Link Project; The Payra 1,320-megawatt coalfired thermal power plant; Multi-lane Road Tunnel project under the river of Karnaphuli in Chittagong which will connect the city with South Chittagong; The Dasherkandi Sewage Treatment Plant Project which is funded by ExportImport Bank of China; Strategic partnership between Ant Finance and Bkash; Mutual Trust Bank's partnership with UnionPay International to jointly operate debit and credit cards with mobile payment services (Surendra, 2019).

Bangladesh is going through major transformations in many areas, it is vital to place itself strongly in the regional and global markets. In light of the China-Bangladesh relations, Dhaka needs to accelerate the strategic formulas to strengthen the current bilateral political and economic ties in the context of Road and Belt Initiative. Some of the areas, which could be considered, are as follows: Garment accessories' exports to China have endured stagnant for the last two years mainly because of exports of simple garment items from Myanmar and Vietnam similar to Bangladesh's exportable items to China for poorer and middle-income groups. To reduce this gap, the Bangladeshi manufacturers and exporters should look to diversify their goods or come up with different RMG export baskets as China's demand for basic garment products, not high-end products, is still moderately high (Surendra, 2019). Besides, Bangladesh is the major machinery market for the Chinese textile and garment machine industrialists. In this regard, Chinese companies can take initiatives to invest in Bangladesh's light engineering sectors, which have the high potential to be the backward linkage for textile machinery industries (Surendra, 2019).

In recent years, Bangladesh has pointed out the tourism industry as a significant area for economic development. Bangladeshi travel agencies provide hospitality and visit guiding training, but the general applied skills level is still little of the demand. Given the China's experiences in development of tourism, the two countries can launch a joint think-tank to advance tourism sector study focusing on culture, training of tourism specialists and other areas. There are, of course, more opportunities for mutual cooperation and mutual advantages between the two neighboring nations. In the era of changing geopolitics, trade and investment, teamwork and collaboration are vital to the existing bilateral relations. So, Dhaka should come forward to apply timely and eligible thoughts to strengthen the Sino-Bangladesh relations (Surendra, 2019). "As an important part of our economic diplomacy, Bangladesh had written to China to exempt our export products from tariffs. In response to this, the State Council Tariff Commission of China has issued an announcement recently. Bangladesh is largely considered among the Least Developed Countries (LDCs) and thus, this decision was taken by the Chinese government", stated Mohammed Touhidul Islam, who is a Senior Information Officer at the Ministry of Foreign Affairs of Bangladesh. "Friday's statement is expected to support Bangladesh mitigate the economic impact of the global pandemic and also help emerge as a probable beneficiary alongside Vietnam and Chile of the U.S.-China trade war in the recent time. Bangladesh usually imports around $\$ 15$ billion in different Chinese products, but its exports to China had been very small in contrast. The supply chain interruption which is caused by U.S.-China trade war is likely to be solved by a boost in exports of tariffexempted goods from Bangladesh. Several business-sectors of Bangladesh are possible to be major beneficiaries of this move. "Bangladesh has already received tariff-exemption for 3095 products under the Asia Pacific Trade Agreement (APTA). On account of the latest declaration, a total of 8256 goods from Bangladesh will be free of charges of Chinese tariffs", (Bhattacherjee, 2020).

In fiscal year of 2018-19, Bangladesh's total exports to China only amounted to $\$ 831.20$ million while it was $\$ 694.97$ million just the former year, according to the Export Promotion Bureau. In the February-July period of 
the current fiscal year, Bangladesh has earned $\$ 470.20$ million through exporting various products to China. Of that total exports, garment products accounted for 80 percent. "Bangladesh, of course, should enjoy the duty-free benefits for 97 percent of its goods and chattels and reject the APTA for the better interest of the country," said Abdur Razzaque, research director of the Policy Research Institute. Presently, there are around 65 Bangladeshi products that are permitted duty-free access to the Chinese markets under the APTA while more than 5,000 goods and chattels enjoy the same benefit under the LDC coverage. "So, Bangladesh desires to accept the 97 percent package," Razzaque explained to the Daily Star, an English newspaper of Bangladesh. It is firmly believed that China would be Bangladesh's third Asian export destination after Japan and India, where the country would be able to send more than $\$ 1$ billion worth of products. At this time, Cambodia and Vietnam are enjoying augmented exports to China as they have preferential trade agreements with the world's most populous country. "If Bangladesh is allowed the 97 percent package, exports to China definitely will increase manifold," Razzaque said (Mirdha, 2020).

The Table 4 shows Bangladesh's total trade with different countries. In terms of both exports and imports China has acquired the first position; and USA acquired the second position. Bangladesh's trade with China is in favor of China. But its trade with USA is in favor of Bangladesh. In the Table 4 it is shown that India is Bangladesh's third largest trading partner where Germany and UK have attained the fourth and fifth position. Bangladesh's trading relations with both Germany and UK are in favor of Bangladesh. The country exports garment accessories to the Western countries including USA, Germany and UK. Bangladesh's RMGs are very popular in those countries considering its quality of the products.

Table 4: Total Trade in Billion US-Dollars

\begin{tabular}{|l|l|l|}
\hline Rank & Country & Total Trade (2016) \\
\hline 1 & China & 15.16 \\
\hline 2 & United States & 6.98 \\
\hline 3 & India & 6.59 \\
\hline 4 & Germany & 6.19 \\
\hline 5 & United Kingdom & 3.80 \\
\hline
\end{tabular}

[Source:

https://en.wikipedia.org/wiki/List_of_the_largest_trading_partner S_of_Bangladesh, accessed on 28th June, 2020]

The Table 4 shows that Bangladesh's largest trading partner is China. USA and India have achieved the second and third position respectively while doing business with Bangladesh. We see that there is a huge trade gap between China and Bangladesh. That the China's exports volume is very high compared to its imports from Bangladesh.
However, recently Chinese investments have grown in the different business sectors and infrastructural development projects in Bangladesh. A number of Bangladeshi students are studying at different universities in China on Chinese government scholarships. The trade imbalance can be minimized through different measures where the BRI and BCMI can play an important role.

The Table 5 discusses about the Bangladesh's top exports destinations. Based on data from the Observatory of Economic Complexity (OEC), the Table 5 shows that Bangladesh's largest export partner is USA; Germany and UK attained second and third position respectively in terms of their imports from Bangladesh. As we have mentioned Bangladesh has a very good image in relation to RMG business in both Europe and America.

Table 5: Bangladesh's Exports in Billion US-Dollar in 2016

\begin{tabular}{|c|c|c|}
\hline Rank & Country & Export (2016) \\
\hline 1 & United States & 6.10 \\
\hline 2 & Germany & 5.49 \\
\hline 3 & United Kingdom & 3.52 \\
\hline 4 & France & 2.73 \\
\hline 5 & Spain & 2.52 \\
\hline 6 & Italy & 1.46 \\
\hline 7 & Japan & 1.22 \\
\hline 8 & Canada & 1.21 \\
\hline 9 & $\begin{array}{l}\text { Belgium } \\
\text { Luxembourg }\end{array}$ & 1.16 \\
\hline 10 & Netherlands & 1.10 \\
\hline 11 & India & 1.02 \\
\hline 12 & Turkey & 0.87 \\
\hline 13 & China & 0.86 \\
\hline 14 & Russia & 0.67 \\
\hline 15 & Denmark & 0.67 \\
\hline 16 & Australia & 0.66 \\
\hline 17 & Poland & 0.66 \\
\hline 18 & Sweden & 0.46 \\
\hline 19 & Switzerland & 0.45 \\
\hline 20 & Czech Republic & 0.39 \\
\hline
\end{tabular}

[Source: The Observatory of Economic Complexity (OEC). https://en.wikipedia.org/wiki/List_of_the_largest_trading_partner s_of_Bangladesh, accesses on 28th June, 2020] 
The Table 6 shows the Bangladesh's top imports partners, based on data from the Observatory of Economic Complexity (OEC). It shows that China is the largest imports partner in Bangladesh. India has secured second position in relation to its exports to Bangladesh. Singapore, Japan and Hong Kong have become the third, fourth and fifth largest imports partner of Bangladesh respectively. Here it should be mentioned that in terms of Bangladesh's total trade with China and India, it is in favor of both China and India. There is huge trade deficit with these two neighboring countries.

Table 6: Bangladesh's Imports in Billion US-Dollar in 2016

\begin{tabular}{|c|c|c|}
\hline Rank & Country & Import (2016) \\
\hline 1 & China & 14.30 \\
\hline 2 & India & 5.57 \\
\hline 3 & Singapore & 2.47 \\
\hline 4 & Japan & 1.54 \\
\hline 5 & Hong Kong & 1.49 \\
\hline 6 & Indonesia & 1.27 \\
\hline 7 & Malaysia & 1.24 \\
\hline 8 & South Korea & 1.16 \\
\hline 9 & Brazil & 1.09 \\
\hline 10 & Thailand & 0.93 \\
\hline 11 & Taiwan & 0.92 \\
\hline 12 & United States & 0.88 \\
\hline 13 & Germany & 0.70 \\
\hline 14 & Pakistan & 0.66 \\
\hline 15 & Australia & 0.61 \\
\hline 16 & Canada & 0.58 \\
\hline 17 & United Arab Emirates & 0.57 \\
\hline 18 & Italy & 0.52 \\
\hline 19 & Argentina & 0.49 \\
\hline 20 & Russia & 0.45 \\
\hline
\end{tabular}

[Source: The Observatory of Economic Complexity (OEC).

https://en.wikipedia.org/wiki/List_of_the_largest_trading_partner s_of_Bangladesh, accesses on 28th June, 2020]

According to Table 6, Bangladesh's largest imports partner is China, and the largest exports partner in USA. Both countries are very potential for Bangladesh for many reasons including political and economic ones. On the contrary, Bangladesh's geo-strategic location is also very significant for both China and USA, that the country has an easy access to South Asia, South East Asia, Indian Ocean and Bay of Bengal. Both China and USA including India are very interested in Bangladesh, particularly in building deep seaports in Sonadia of Cox's Bazar for its strategic position in the Bay of Bengal bordering with the state of Rakhine in Myanmar, which can be used by both China and India through small land of Myanmar, if the port is constructed. But, on security ground, the Indian government pressurizing Bangladesh to keep refrained from implementing the project financed by the Chinese government that the port may be used for military purposes by the Chinese naval force. By this way, the Chinese investment is being hindered by the India through which Bangladesh could have been benefitted economically to a large extent.

\section{China-Pakistan Trade, Investment and Economic Relations}

The second stage of China-Pakistan Free Trade Agreement (CPFTA-II) which is a massive step and it offers abundant facilities and opportunities to Pakistan's business community. These remarks were made by Saboor Malik, President of Rawalpindi Chamber of Commerce and Industry (RCCI) while addressing at a seminar organized by the Trade Development Authority of Pakistan (TDAP) on Saturday. Mr. Malik said, 'it was an important initiative to liberalize trade and investment and revitalize the remaining strategic and economic partnership between Pakistan and China. "Pakistan will be able to increase its export by $\$ 1$ billion in short term whereas the export of these products is likely to touch $\$ 4-5$ billion in the medium term later setting up new trade and industries in the special economic zones being built in Pakistan under the China-Pakistan Economic Corridor (CPEC)," he stated. The RCCI president said China had removed tariffs on 313 Pakistani products. Tariff lines comprise textile, garments, seafood, prepared food, animal products, leather, plastic chemicals, oil seeds and engineering goods including tractors, home appliances auto parts, gems and jewelry, cement, plastics, footwear, rubber, chemicals, paper and semi-finished goods (The Dawn, 2020). But it mostly comprises non-technological goods. Mr. Malik warned that by exporting only agro-products, Pakistan could not subsist in the 21 st century. The country necessities to increase its technological developments and exports to catch up with the growing economies of the world, he added. He wanted that producers and existing industries of Pakistan that have straight significance and export prospective should be facilitated with the required support from the government. The government of Pakistan should consider enabling exporters who face interruption in getting permission through state banks, he said, in addition that a lot of work required to be done in cooperation with government institutions to earn benefits of the ChinaPakistan Free Trade Agreement Phase 2."There is a necessity for conducting consciousness sessions on the subject of China-Pakistan Free Trade Agreement. Still 
publics do not know about GSP and GSP Plus granted by Europe and America and only a few sectors are receiving restricted benefits from these facilities. We intensely endorse that this agreement should be publicized on mass level so that we can achieve full businesses benefit from these opportunities," he said (The Dawn, 2020).

In coming years, when CPEC projects will be accomplished and run in full steam, Pakistan is certain to record a further increase in imports, largely from China but also from other countries (Ahamed, 2020). It is time to concentrate on some technical and financial resources to draw an entire map to determine how exports to the whole world, and more precisely to China, can grow. Pakistan cannot afford to run a massive trade imbalance with any trading partner. At present China has turned itself into the second largest economy of the world; but the country has a huge trade deficit with its neighboring countries including Pakistan. Islamabad should, of course, renegotiate some provisions of its trade deals with Beijing with the special purpose of stimulating exports to the Chinese markets. It is absolutely desirable and it is quite possible (Ahamed, 2020). The Chinese side would most likely to increase in value that by allowing greater concessions in tariff lines of imports from Pakistan, it would help its industries, enterprises and businesses do more trade with a country where there are greater chances for them to enter via CPEC. Won't they? Within ongoing discomfort between Sino-Indian relationship, China can definitely shift part of its imports that were previously procured from India to Pakistan now. It is high time to come up with practical options for decreasing Islamabad's trade deficit with China. It depends on the political leadership of the two countries to sort out this issue as early as possible. That will also develop their strategic geopolitical ties (Ahamed, 2020).

Pakistan has exported to China US\$2.04 Billion during 2019, (tradingeconomics.com, June, 2020). As per the data of the State Bank of Pakistan, Pakistan's exports to China have increased from $\$ 1.8$ billion in the fiscal year of 2018 to $\$ 1.9$ billion in the fiscal year of 2019. In terms of percentage, the share of exports to China has risen from 7.2 percent in total exports in the fiscal year of 2018 to $7.7 \%$ in the fiscal year of 2019. Major export items include cotton yarn, rice, alcohol and other spirits, copper and related products and chromium ores. It is worth mentioning that these items are contributing over 60 percent of the total exports to China which indicates a low export base of Pakistan (Javed, 2019). Pakistan has imported Chinese products for the cost US\$12.4 Billion during 2019, (tradingeconomics.com, 2020).

The Table 7 discusses about Pakistan's largest export partners. It shows that Pakistan's largest exports partner is USA, not China or India. But China has secured the second position in terms of its exports. According to the Table 7 it shows that Pakistan's largest imports partner is China. UAE is Pakistan's second largest imports partner. Its exports to China are $7.7 \%$ of total exports, where its exports to USA are $16.1 \%$. It is also true that there is a huge trade deficit between Pakistan and China. Pakistan hopes to reduce the remaining trade imbalance through the CPEC and BRI.

Table 7: Main Exports Partners of Pakistan in 2018

\begin{tabular}{|l|l|}
\hline Main Customers (\% of Exports) & $\mathbf{2 0 1 8}$ \\
\hline United States & $16.1 \%$ \\
\hline China & $7.7 \%$ \\
\hline United Kingdom & $7.3 \%$ \\
\hline Germany & $5.5 \%$ \\
\hline United Arab Emirates & $4.2 \%$ \\
\hline See More Countries & $59.2 \%$ \\
\hline
\end{tabular}

[Source: Comtrade, 2020. Because of rounding, the sum of the percentages may be smaller/greater than $100 \%$.]

The Table 8 discusses about Pakistan's top imports partners. It shows that Pakistan's top imports partner is China. Its imports from China are $24.2 \%$ of total imports. UAE and KSA has become Pakistan's second and third imports partner respectively. Its imports from the USA are only $4.9 \%$ of the total imports.

Table 8: Main Imports Partners of Pakistan in 2018

\begin{tabular}{|l|l|}
\hline Main Suppliers & $\begin{array}{l}\text { \% of Imports } \\
(\mathbf{2 0 1 8})\end{array}$ \\
\hline China & $24.2 \%$ \\
\hline United Arab Emirates & $14.4 \%$ \\
\hline Saudi Arabia & $5.4 \%$ \\
\hline United States & $4.9 \%$ \\
\hline Indonesia & $4.2 \%$ \\
\hline See More Countries & $47.0 \%$ \\
\hline
\end{tabular}

[Source: Comtrade, 2020. Because of rounding, the sum of the percentages may be smaller/greater than $100 \%$.]

Here, it can be said that the trade imbalance between Pakistan and China is huge, it can be solved through bilateral negotiations and increasing trade volume between the two nations. Particularly, Pakistan's exports should be increased to China to minimize the gap.

\section{China-Nepal Trade, Investment and Economic Cooperation}

Nepal-China economic cooperation was started from the very beginning of formalization of bilateral relations in 1950's. The first "Treaty between China and Nepal on development cooperation" was first signed in the month of 
October 1956. From the mid-80s, the Chinese Government has been providing grant assistance to the Government of Nepal and its people under the Financial and Technical Cooperation Program so as to implement jointly acceptable development projects. Chinese development assistance and cooperation in Nepal fall into three categories: aid grants, loans free of interest and concessional loans. The Chinese economic and official assistance to Nepal has significantly contributed to Nepal's socio-economic and infrastructural development efforts in the areas of infrastructure construction, industrialization process, human resources development program, healthcare, education and training, water resources management, sports, physical exercises and the like, (MOFA, 2020).

Some of the main running projects under Chinese assistance include: Development of Trishuli Hydropower ProjectPower station and Transmission Line Projects; Material Assistance in northern 15 bordering districts; Kathmandu Ring Road Improvement Project; Development of Civil Service Hospital; Larcha (Tatopani) and Timure (Rasuwagadi) Frontier Inspection Station Project; Development of Syaprubensi-Rasuwagadhi Road; Pokhara International Regional Airport; Development of Kodari Highway and restoration of bordering bridges at Kodari and Rasuwagadhi.

On the signing of the Memorandum of Understanding on Cooperation and development under the Belt and Road Initiative on 12 May 2017 in Kathmandu between Nepal and China, now the new opportunities for joint cooperation in development related areas are likely to start quickly. The major drive of the MoU is to encourage mutually beneficial issues between Nepal and China in several fields such as economic development, environmental protection, technological development and cultural exchange. Moreover, the MoU aims at upholding collaboration on policy exchanges, infrastructure connectivity, trade connectivity, financial integration and connectivity of people of the two neighboring countries (MOFA, 2020). China provided considerable and impulsive support in search, relief and rescue efforts of Nepal following the shocking earthquakes of 2015. At that time, China provided 3 billion Yuan on Nepal's reconstruction to be used in the jointly selected 25 major development projects for the period of 2016-2018. The governments of two countries signed three separate joint Treaties on Financial and Technical Cooperation on 23 December 2016, 15 August 2017 and 21 June 2018 for ensuring to provide Chinese grant of one billion Yuan each to Nepal to take required steps to implement post-disaster restoration projects, income projects and other jointly agreed projects (MOFA, 2020).

China has surpassed in FDI pledges to Nepal in FY 201516, 2016-17 and in 2017-18 with the rising investment commitments from the Chinese business conglomerates in cement, hydropower, herbal medicine and tourism (MOFA, 2020). China is the second largest source of foreign travelers to Nepal. During the year 2018, 164,694 Chinese tourists have paid visit to the naturally beautiful Nepal where the Himalayas are exist. The Government of Nepal has taken initiative to waive visa fees for the Chinese tourist which was effective from 1 January 2016. The Chinese Government declared the year of 2017 as Nepal Tourism Promotion Year in China. In light of the upcoming Visit Nepal Year 2020, both sides have been carrying out joint efforts to inspire Nepal in China and encourage Chinese enterprises to invest in Nepal's travel sectors. Nepal has road connectivity with China via Rasuwagadhi and Tatopani for trade purposes and for international travelers. There are four other border immigration points built for bilateral trades. Nepal has also direct air link with Lhasa, Kunming, Chengdu, Guangzhou and Hong Kong SAR of China (MOFA, 2020). Many Nepalese scholars think that the bilateral cooperation will continue to grow on many issues such as trade, investment, development cooperation, education and training and promoting development activities in Nepal through the BRI because of the friendly relations between the two neighboring nations. Also some Nepalese students are studying at different universities of China on Chinese government scholarship. Also Nepal will be greatly benefitted economically and geo-politically through the BRI and other regional connectivity platforms of China.

\section{Conclusion}

In the Political Report at the 19th Party Congress in October 2017, General Secretary, President Xi Jinping set a new target for China to become "great modern socialist country" by the middle of the twenty-first century, and proposed to encourage the building of a "community of shared future for mankind." Furthermore, the Central Work Conference on Foreign Affairs, which set out the basic policies of Chinese diplomacy, was held in June 2018 after four years' interval. During the Conference, Xi Jinping declared that "standing firm on national sovereignty, security, and development interests, we will, of course, actively get involved in and lead the reform of global governance and open up a new phase of great power diplomacy with Chinese characteristics." In this context, the BRI is regarded as a practice to build a community of shared future for mankind. China's opening-up policy under the $\mathrm{Xi}$ Jinping administration no longer means the development of specific bilateral relations and the specific requirements to introduce foreign currency and technology but represents the response to multilateral international relations as an economic superpower. China's involvement in global governance tends to be inevitably reinforced in the foreseeable future.

In major multilateral relations, at present, China is likely to be reform oriented by taking a leadership position within 
the regime rather than challenging the existing international regime. With regard to multilateral regime in a process of formation, as mentioned above, China tends to pursue its own way. The relationship between China and the BRI countries is also a place for experimentation toward the formation of an economic area led by China. In fact, however, along with the progress of the BRI projects, a sense of disappointment is also spreading among some of the BRI countries with China-led project delays and huge debts to China. The impression that China poses a "threat" is on the rise around the globe. It is a threat that China as an economic superpower would form an exclusive economic area based on the BRI and become a new global rule maker instead of G7.

Looking at the relationship with the BRI countries and considering the existing development aid/ finance regime, we have come to the conclusion that China's capacity and intention to create new global norms and rules are really limited. By pursuing the opening-up policy, China has benefited from trade and FDI by taking an almost "free ride" on the global free trade system. China is likely to enjoy these benefits in future with burdening minimum costs of becoming a rule maker. Ironically, current trends of undermining free trade system with rising protectionism are not necessarily favorable for China. It is the most favorable scenario for China to continue reaping the fruits of free trade system, while forming a China-led economic area with the BRI countries in the backyard. However, South Asian countries highly appreciate China for its status as one of the world's rapidly growing economies. The economic revolution has been so rapid that China is projected by some scholars to become the world's largest economic power by 2050 with a GDP of $\$ 44.4$ trillion ahead of the US GDP of $\$ 35$ trillion. The subsequent economic strength and power of China has generated the impulse for a closer relation with South Asian nations. We are very happy to see China's growing concentration in forging economic and strategic partnerships in South Asia nations including our country, Bangladesh, through the Belt and Road Initiative (Ahamed, 2013).

Finally, it can be said that there is a huge trade deficit among China and South Asian countries which need to be resolved with proper measures. China should come ahead to reduce the existing trade gap in the region, because trade relations in the region is in favor of China. Trade imbalance is a cause of lack of trust between China and South Asia. India and Pakistan should maintain friendly relations in terms of geopolitics and economic relations; and both China and India should work together to achieve peace and stability in the region. Without stable political environment, business interests can never be attained in any way.

\section{Conflict of Interest}

Authors declare no any conflict of interest with the present work.

\section{Acknowledgement}

The second author of this study was involved in a Research project, title of which is: "Rise of China and Future of South Asia", which was financed by the World Bank and implemented by the Ministry of Education, Bangladesh, and University Grants Commission of Bangladesh. The Research project was directed by Professor Dr. Bhuian Md. Monoar Kabir of Political Science Department at the University of Chittagong. As a member of the Research Project, along with the entire research team under the leadership of Project Director, Professor Dr. Bhuian Md. Monoar Kabir, the second author paid visits to these universities: Delhi University, Institute of Defense Studies and Analysis (IDSA), Delhi, India, Karachi University, Pakistan, Tribhuvan University, Kathmandu, Nepal, Yunnan University for Finance and Economics, Kunming, The Academy of Social Sciences, Beijing and The Academy of World Watch, Shanghai, China. And the author attended a number of International seminars in 2012 and 2013 in the above mentioned countries on "Rise of China and Future of South Asia". Both authors are grateful to the Research Project.

\section{References}

Ahamed A (2013) Sino-South Asian Relations: Economic and Strategic Implications for Bangladesh. In: Kabir BMM (eds.) Sino-South Asian Relations: Continuity and Change, Department of Political Science, University of Chittagong, pp. 242-279.

Ahmed SH (June 8, 2020) Improving trade balance with China, The Express Tribune Business, https://tribune.com.pk/story/2237699/2-improving-tradebalance-china/

Bhattacherjee K (19 June, 2020) Now, China embraces Bangladesh in trade https://www.the hindu.com/news/international/now-china-embracesbangladesh-in-trade/article31868260.ece (Accessed, 27th June, 2020)

Guruswamy M (21 May, 2017) “India's Unfounded Fears: For China, One Belt One Road is About Economics - not World Domination"

Jain BM (1991) China in South Asia: Security Aspects, Monograph, ICSSR, New Delhi, pp 10-11.

Javed A (6 September, 2019) Pakistan China trade: where we standhttps://dailytimes.com.pk/461070/pakistan-chinatrade-where-we-stand/

Kapoor M (20 June, 2020) Six Things to Know about India-China Economic Relations. https://www.bloombergquint.com/economy-finance/sixthings-to-know-about-india-china-economic-relations 
Lams L (2018) Examining Strategic Narratives in Chinese Official Discourse under Xi Jinping. Journal of Chinese Political Science 23: 387-411.

Ministry of External Affairs (MEA), Government of India, (5 April, 2018) “Official Spokesperson's Response to a Query on Media Reports Regarding Possible Cooperation with China on OBOR/BRI"

Mirdha, RU (28 June, 2020) Bangladesh to gain more trade benefits from China as an LDC, https://www.thedailystar.net/business/news/bangladeshgain-more-trade-benefits-china-ldc-1882324MOFA

(June, 2020) Nepal-China Relations, Government of the people's republic of Nepal, Ministry of Foreign Affairs, North East Asia Division. https://mofa.gov.np/nepal-china relations/?fbclid=IwAR3q2bjr284xTQ5CeVgImokpjj922 tV5ePfLlgHjfJ2fCkeFy_RRIRN7ABI

Rana KS (September, 2017) China's Belt and Road Initiative: Impact on India and the China Diplomacy, ICS Occasional Paper 16: 1-27.

Singh S (April, 2000) Sino South Asian Ties: Problems and Prospects, Strategic Analysis, pp.31.

Summers T (2016) Thinking inside the box: China and global/regional governance. Rising Powers Quarterly 1(1): 23-31.
Summers T (2018) Rocking the boat? China's 'belt and road' and global order. In: Ehteshami A \& Horesh N (eds.) China's Presence in the Middle East: The implications of the One Belt, One Road Initiative. New York: Routledge.

Surendra SYK (June, 2019) International Journal of China Studies China's Belt and Road Initiative (BRI): India's Concerns, Responses and Strategies, Bangalore University, 27 Vol. 10, No. 1, pp. 27-45

Tekdal V (2018) China's Belt and Road Initiative: At the Crossroads of Challenges and Ambitions, The Pacific Review 31(3): $\quad 373-390 . \quad$ DPO: https://doi.org/10.1080/09512748.2017.1391864

The Dawn (19 January, 2020) Pakistan can increase exports to China up to $\$ 4-5$ billion in medium run under CPFTA-II, http://cpecinfo.com/pakistan-can-increase-exports-tochina-up-to-4-5-billion-in-medium-run-under-cpfta-ii/ tradingeconomics.com, (29th June, 2020). https://tradingeconomics.com/?fbclid=IwAR1BS8cRjnI1 FIdPCmVqd_PnIVzOrZA_MqIHTUNbhTbBQfeTjej1ideCtE

Yucheng L (15 October, 2018) Remarks by Executive Vice Foreign Minister, At the Welcoming Dinner of The First Meeting of the Advisory Council of The Belt and Road Forum for International Cooperation (BRF)South Asia Regional Overview, (21 November, 2018) South Asian Regional Development Gateway. 